\title{
Triplet Pregnancy
}

National Cancer Institute

\section{Source}

National Cancer Institute. Triplet Pregnancy. NCI Thesaurus. Code C111957.

A pregnancy involving three fetuses. 